\title{
PERBEDAAN TINGKAT PENGUNGKAPAN ANTARA PERUSAHAAN ASING DAN DOMESTIK \\ DENGAN ADANYA KONVERGENSI IFRS
}

\author{
Disusun oleh: \\ Yohana Heru Krisna Silviana \\ NPM: 100418248 \\ Pembimbing \\ Pratiwi Budiharta \\ Program Studi Akuntansi \\ Fakultas Ekonomi \\ Universitas Atma Jaya Yogyakarta \\ Jalan Babarsari 43-44, Yogyakarta
}

\begin{abstract}
Abstrak
Tujuan dari penelitian ini adalah untuk mengetahui perbedaan tingkat pengungkapan antara perusahaan asing dan domestik. Penelitian ini memfokuskan pada perusahaan yang termasuk dalam Penanaman Modal Asing (PMA) dan Penanaman Modal Dalam Negeri (PMDN). PMA merupakan kriteria untuk perusahaan asing, sedangkan PMDN merupakan kriteria untuk perusahaan domestik dalam penelitian ini. Dari 450 perusahaan yang diobservasi, diperoleh 86 perusahaan sebagai sampel, dengan metode purposive sampling untuk mengambil sampel. Penelitian ini menggunakan uji Chi-Square dan uji Mann-Whitney-Wilcoxon untuk uji analisisnya. Penelitian ini menggunakan IFRS disclosure checklist dari PwC untuk menganalisis tingkat pengungkapannya. Tingkat pengungkapan diukur dengan menggunakan Total Disclosure Ratio. Penelitian ini menemukan bahwa terdapat perbedaan tingkat pengungkapan antara perusahaan asing dan domestik.
\end{abstract}

Kata Kunci: tingkat pengungkapan, perusahaan asing, perusahaan domestik, dan IFRS. 


\section{Pendahuluan}

\subsection{Latar Belakang}

Bidang akuntansi saat ini sedang mengalami perkembangan yang mengarah pada penerapan standar akuntansi global yang tunggal, yaitu dengan adanya International Financial Reporting Standards (IFRS) yang dirumuskan oleh International Accounting Standards Board (IASB). IASB memiliki tujuan yaitu agar semua negara dapat mengadopsi IFRS secara penuh, sehingga informasi yang diperoleh dari laporan keuangan menjadi lebih berkualitas, transparan, serta dapat lebih mudah diperbandingkan. Saat tujuan ini tercapai, maka pelaporan keuangan di tingkat global akan menggunakan IFRS sebagai standarnya.

Isu penting yang terjadi di Indonesia beberapa tahun terakhir ini adalah pengungkapan dan transparasi dalam laporan keuangan. Pemerintah Indonesia sebagai salah satu anggota dari The Group of Twenty (G20 Forum) telah menyepakati untuk melakukan konvergensi terhadap IFRS, yang bertujuan untuk meningkatkan kualitas informasi pada laporan keuangan perusahaan-perusahaan di Indonesia.

Adopsi IFRS merupakan alternatif yang paling murah untuk meningkatkan kualitas informasi pelaporan keuangan untuk mendukung alokasi modal yang efisien serta untuk menarik minat para investor agar membiayai pertumbuhan ekonominya (Nobes, 2010). Diharapkan konvergensi IFRS mampu meningkatkan kualitas informasi pada laporan keuangan perusahaan yang berada di Indonesia serta memungkinkan adanya pertukaran dan perbandingan informasi secara universal.

Menurut hasil penelitian Sudarmadji dan Sularto (2007) ditemukan bahwa ratarata tingkat pengungkapan sukarela sangat rendah sekali, yakni hanya sebesar $37 \%$. Di negara Mesir, rata-rata tingkat pengungkapan wajibnya sebesar 55\% pada seluruh sektor dan ini masih terbilang rendah (Dahawy, 2009). Bova dan Pereira (2012) menyatakan bahwa tingkat pengungkapan pada perusahaan publik lebih tinggi daripada perusahaan pribadi dan kepemilikan asing berpengaruh signifikan positif terhadap tingkat pengungkapan.

Dengan melihat penelitian-penelitian yang telah dilakukan, penulis mencoba untuk meneliti tingkat pengungkapan antara perusahaan asing dan domestik di Indonesia pada tahun 2009 hingga 2012. Hal yang membedakan penelitian ini dengan penelitian sebelumnya adalah dalam mengukur tingkat pengungkapan IFRS pada penelitian ini digunakan IFRS disclosure checklist dari PricewaterhouseCoopers (PwC).

Berdasarkan latar belakang di atas, maka penelitian ini diberi judul "Perbedaan Tingkat Pengungkapan antara Perusahaan Asing dan Domestik"

\subsection{Rumusan Masalah}

1. Apakah terdapat perbedaan tingkat pengungkapan antara perusahaan asing dan perusahaan domestik? 
2. Seberapa besar perbedaan tingkat pengungkapan antara perusahaan asing dan perusahaan domestik?

\subsection{Batasan Masalah}

Batasan masalah dalam penelitian ini adalah:

1. Data yang digunakan adalah laporan tahunan untuk tahun 2009-2012.

2. Kriteria perusahaan asing dalam penelitian ini adalah perusahaan yang termasuk dalam PMA (Penanaman Modal Asing).

3. Kriteria perusahaan domestik dalam penelitian ini adalah perusahaan yang termasuk dalam PMDN (Penanaman Modal Dalam Negeri).

4. IFRS disclosure checklist dari $\mathrm{PwC}$ yang digunakan pada penelitian ini hanya menggunakan IFRS disclosure checklist section A (bagian General Disclosure) dan section $D$.

\subsection{Tujuan Penelitian}

Tujuan penelitian ini ialah memberi bukti empiris bahwa terdapat perbedaan tingkat pengungkapan antara perusahaan asing dan perusahaan domestik.

\subsection{Manfaat Penelitian}

1. Dalam kontribusi teori, manfaat penelitian ini adalah memberikan bukti empiris tentang perbedaan tingkat pengungkapan antara perusahaan asing dan perusahaan domestik.

2. Dalam kontribusi praktik, manfaat penelitian ini adalah untuk membantu investor, pemegang saham, dan manajemen dalam membuat keputusan serta memahami pentingnya tingkat pengungkapan pada laporan keuangan.

3. Dalam kontribusi kebijakan, manfaat penelitian ini adalah sebagai feedback untuk melakukan evaluasi atas efektifitas peraturan yang telah dibuat dan perbaikan yang mungkin harus dilakukan ke depannya.

\section{Landasan Teori dan Pengembangan Hipotesis}

Hubungan keagenan muncul ketika terdapat kontrak antara satu pihak (prinsipal) yang mengikat pihak lainnya (agen) untuk melakukan jasa demi kepentingan prinsipal. Dengan adanya kontrak tersebut, prinsipal mendelegasikan beberapa wewenang pembuatan keputusan kepada agen. Irfan (2002) menyatakan bahwa antara prinsipal dan agen biasanya terdapat ketidakseimbangan informasi karena agen memiliki informasi yang lebih banyak tentang perusahaan dibandingkan dengan prinsipal. Oleh karena asimetri informasi mempengaruhi dalam proses pembuatan keputusan, maka diperlukan 
suatu media untuk mengurangi asimetri informasi yang ada. Media komunikasi yang digunakan antara agen dengan prinsipal adalah pelaporan keuangan.

Tingginya permintaan mengenai pengungkapan pada laporan tahunan yang semakin meningkat menjadi salah satu penyebab terjadinya peningkatan pengungkapan dalam laporan tahunan perusahaan-perusahaan yang ada di dunia saat ini. Adanya IFRS diharapkan dapat meminimalkan keberagaman dalam standar akuntansi yang ada sebelumnya, sehingga dapat memberi kemudahan dalam memahami apa yang diungkapkan dalam laporan tahunan dan dapat melakukan perbandingan antarperusahaan. Oleh karena itu, perombakan standar akuntansi yang mengacu pada IFRS tetap harus dilakukan, terutama untuk perusahaan-perusahaan yang listing di Bursa Efek Indonesia (BEI) agar dapat mempermudah menjalin kerjasama dengan investor asing. Semakin meningkatnya permintaan mengenai pengungkapan dalam laporan tahunan, membuat persaingan antarperusahaan menjadi semakin ketat untuk menarik calon investor baik yang berasal dari dalam negeri maupun luar negeri. Agar dapat menarik para investor asing, maka dibutuhkan pengungkapan yang lebih luas dan sesuai dengan standar akuntansi internasional.

Menurut Susanto (1992), perusahaan yang berbasis asing mungkin melakukan pengungkapan yang lebih luas. Hal ini didukung dengan pernyataan Pramono (2006) bahwa dengan melakukan investasi langsung, investor dapat mengendalikan manajemen. Selain itu dengan adanya PMA, perusahaan yang ada di negara asal dapat mengendalikan perusahaan yang ada di negara tujuan investasi baik sebagian atau seluruhnya. Dengan adanya pengendalian tersebut, maka para investor dapat menuntut tingkat pengungkapan yang lebih tinggi dan penggunaan standar akuntansi global yang ada. Untuk dapat lebih mudah dalam melakukan perbandingan dengan perusahaan asing, maka perusahaan domestik dianjurkan untuk menggunakan standar akuntansi global yang ada. Dengan digunakannya standar akuntansi internasional, maka para investor dapat dengan mudah melakukan analisis perbandingan antarperusahaan baik dari dalam negeri maupun lintas negara. Dengan adanya penerapan standar tersebut, maka tidak dipungkiri akan adanya persaingan bisnis antara perusahaan asing dan domestik.

Agar dapat memperluas usahanya, perusahaan domestik dianjurkan untuk mengikuti standar akuntansi global yang ada. Bila mengikuti standar akuntansi global, maka diharapkan tingkat pengungkapan pada laporan keuangan tahunan menjadi lebih tinggi dibandingkan sebelumnya. Sisi positif lainnya yang dapat diperoleh adalah kemungkinan menarik perhatian investor asing untuk menanamkan modalnya pada perusahaan domestik di Indonesia, sehingga dapat memperluas usaha perusahaan domestik tersebut.

Penelitian mengenai tingkat pengungkapan dan dampak dari adanya konvergensi IFRS telah diteliti, baik oleh peneliti dari luar negeri maupun dari dalam negeri. Berikut ini akan dijelaskan beberapa ringkasan mengenai penelitian terdahulu yang berasal dari luar dan dalam negeri.

Penelitian oleh Bova dan Pereira (2012) yang berjudul 'The determinants and consequences of heterogeneous IFRS compliance level following mandatory IFRS 
adoption: evidence from developing country' menunjukkan bahwa tingkat pengungkapan pada perusahaan publik lebih tinggi daripada perusahaan pribadi dan kepemilikan asing berpengaruh signifikan positif terhadap tingkat pengungkapan. Penelitian Mardini et al. (2012) yang berjudul 'The impact of IFRS 8 on disclosure practices of Jordanian listed companies' memberikan hasil adanya peningkatan pada pengungkapan jumlah segmen dan item pada segmen di laporan keuangan perusahaanperusahaan tersebut.

Penelitian di Indonesia dilakukan oleh Utami et al. (2012) dengan judul 'Investigasi dalam konvergensi IFRS di Indonesia: Tingkat kepatuhan pengungkapan wajib dan kaitannya dengan mekanisme corporate governance'. Penelitian ini menunjukkan hasil bahwa tingkat kepatuhan pengungkapan wajib IFRS di Indonesia masih kurang dan mekanisme corporate governance dengan proksi kepemilikan manajerial dan kepemilikan institusional mempengaruhi tingkat kepatuhan pengungkapan wajib IFRS. Variabel lainnya yaitu jumlah rapat dewan komisaris, jumlah rapat komite audit, dan proporsi independen tidak berpengaruh terhadap tingkat kepatuhan pengungkapan wajib tersebut. Penelitian Farahmita (2012) yang berjudul 'Analisis faktor-faktor yang mempengaruhi kemungkinan adopsi IFRS di negara berkembang'. Penelitian ini menunjukkan bahwa kualitas regulator secara positif mempengaruhi kemungkinan adopsi IFRS di negara berkembang, sedangkan untuk faktor yang lain berpengaruh secara negatif.

Di tengah maraknya penerapan IFRS di berbagai negara, penulis mempunyai ekspektasi bahwa perusahaan asing memiliki tingkat pengungkapan yang berbeda dengan perusahaan domestik. Alasannya pemilik asing menuntut adanya pengungkapan yang lebih dan yang sesuai dengan standar akuntansi internasional yang ada agar dapat lebih mudah melakukan perbandingan dengan laporan tahunan perusahaan yang berada di negara lain. Hadi dan Sabeni (2002) menjelaskan bahwa perusahaan asing mendapat pelatihan yang lebih baik dalam bidang akuntansi dari perusahaan induk di luar negeri, perusahaan asing mungkin memiliki sistem informasi yang lebih efisien untuk memenuhi kebutuhan internal dan perusahaan induk serta kemungkinan permintaan yang lebih besar pada perusahaan berbasis asing dari pelanggan, pemasok, dan masyarakat umum.

Berdasarkan penjelasan tersebut, peneliti merumuskan hipotesis sebagai berikut:

\section{$H_{1}$ : Terdapat perbedaan tingkat pengungkapan antara perusahaan asing dan domestik.}

Selain itu, penulis juga mempunyai ekspektasi bahwa perusahaan asing memiliki tingkat pengungkapan yang lebih tinggi bila dibandingkan dengan perusahaan domestik. Alasannya adalah pemilik perusahaan sebisa mungkin mengikuti dan mendukung penerapan standar akuntansi global yang tunggal agar dapat bertahan dalam persaingan bisnis internasional serta para pengguna informasi dapat memperoleh laporan tahunan yang lebih berkualitas, transparan, serta dapat lebih mudah membandingkan antara laporan keuangan yang satu dengan yang lainnya. Untuk perusahaan domestik yang berada di Indonesia tentunya juga mengikuti standar akuntansi global yang ada, tetapi 
lebih lambat. Hal ini dikarenakan Indonesia perlu melakukan konvergensi dan tentunya membutuhkan waktu yang tidak singkat. Sedangkan, untuk perusahaan asing dapat lebih dahulu mengikuti standar akuntansi internasional tersebut karena adanya tuntutan dari pemilik perusahaan tersebut ataupun karena telah mengikuti standar yang ditetapkan oleh perusahaan induknya di luar negeri. Selain itu, perusahaan dengan kepemilikan asing tinggi memiliki teknologi yang cukup, skill karyawan yang baik, jaringan informasi yang luas, sehingga memungkinkan untuk melakukan disclosure secara lebih luas dan lebih baik (Almilia dan Retrinasari, 2007).

Berdasarkan penjelasan tersebut, peneliti merumuskan hipotesis sebagai berikut:

\section{$\mathrm{H}_{2}$ : Tingkat pengungkapan perusahaan asing lebih tinggi daripada perusahaan domestik.}

\section{Metodologi Penelitian}

\subsection{Jenis Penelitian}

Jenis penelitian yang digunakan adalah penelitian empiris yaitu dengan melakukan pengujian hipotesis.

\subsection{Populasi dan Sampel}

Tabel 3.1

Sampel Data Perusahaan Asing

\begin{tabular}{|l|c|}
\hline \multicolumn{1}{|c|}{ Keterangan } & Jumlah \\
\hline $\begin{array}{l}\text { Perusahaan yang terdaftar di BEI hingga } \\
\text { tahun } 2012\end{array}$ & 450 \\
\hline Perusahaan yang termasuk dalam PMDN & $(366)$ \\
\hline Data tidak lengkap & $(41)$ \\
\hline Jumlah sampel & 43 \\
\hline
\end{tabular}

Sampel perusahaan domestik dipilih yang sesuai dengan industri perusahaan asing dan sebanding dengan jumlah perusahaan asing. Hal ini bertujuan agar penelitian tidak memberikan hasil yang bias.

\subsection{Definisi Operasional dan Pengukuran Variabel Penelitian}

\subsubsection{Variabel Independen}

Variabel independen dalam penelitian ini adalah perusahaan, yang dibagi menjadi dua, yaitu perusahaan asing dan perusahaan domestik. Sampel perusahaan dipilih sesuai 
dengan kriteria yang telah ditentukan. Sampel yang telah dipilih kemudian diberikan kode untuk memudahkan dalam proses analisis. Untuk sampel perusahaan asing diberi kode ' 1 ' dan untuk perusahaan domestik diberi kode ' 2 '.

\subsubsection{Variabel Dependen}

Variabel dependen dalam penelitian analisis perbedaan ini adalah tingkat pengungkapan, yang diproksikan dengan menggunakan daftar pengungkapan (disclosure checklist) tahun 2012 dari PwC (PricewaterhouseCoopers). Untuk keperluan tersebut maka alat analisis yang digunakan adalah Total Disclosure Ratio.

\subsubsection{Total Disclosure Ratio}

Total Disclosure Ratio digunakan untuk membandingkan total jumlah item yang diungkapkan dalam laporan keuangan dengan jumlah item pengungkapan yang terdapat pada daftar pengungkapan. Jika item yang terdapat dalam daftar pengungkapan diungkapkan dalam laporan keuangan perusahaan, maka akan diberikan nilai 1 . Sedangkan bila item tersebut tidak diungkapkan, maka akan diberikan nilai 0. Rasio Total Disclosure dirumuskan sebagai berikut:

$$
T D=\sum_{i=1}^{m} d_{i} / m
$$

keterangan:

$\mathrm{TD}=$ total disclosure

$d i=$ total jumlah item yang diungkapkan pada saat adanya konvergensi IFRS.

$\mathrm{m}=$ total item yang termasuk dalam disclosure checklist (105 item).

Hasil dari Total Disclosure Ratio kemudian dikelompokkan untuk lebih memudahkan dalam proses analisis. Hasil pengelompokkan Total Disclosure Ratio disajikan dalam Tabel 3.2. sebagai berikut:

Tabel 3.2.

Pengelompokkan Total Disclosure Ratio

\begin{tabular}{|c|c|c|}
\hline No. & Keterangan & Total Disclosure Ratio \\
\hline 1 & Sangat Rendah & $0,00-0,20$ \\
\hline 2 & Rendah & $0,21-0,40$ \\
\hline 3 & Sedang & $0,41-0,60$ \\
\hline 4 & Tinggi & $0,61-0,80$ \\
\hline 5 & Sangat Tinggi & $0,81-1,00$ \\
\hline
\end{tabular}




\subsection{Jenis dan Teknik Pengumpulan Data}

Jenis data yang digunakan dalam penelitian ini adalah data sekunder berupa laporan tahunan (annual report) tahun 2009 sampai dengan tahun 2012. Laporan tahunan dapat diperoleh dari website Bursa Efek Indonesia (www.idx.co.id) dan website dari masing-masing perusahaan.

\subsection{Model Penelitian}

\section{Hipotesis 1}

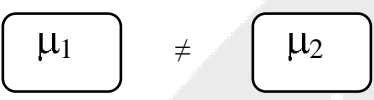

\section{Hipotesis 2}

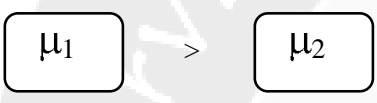

Keterangan:

$\mu_{1}=$ Tingkat pengungkapan pada perusahaan asing.

$\mu_{2}=$ Tingkat pengungkapan pada perusahaan domestik.

\section{Analisis Data dan Pembahasan}

\subsection{Statistik Deskriptif}

Tabel 4.1

Statistik Deskriptif

\begin{tabular}{|l|r|r|r|r|r|}
\hline \multicolumn{7}{|c|}{ Descriptive Statistics } \\
\hline & N & Mean & Std. Deviation & Minimum & Maximum \\
\hline KODETDR & 344 & 3,46 &, 703 & 2 & 5 \\
\hline KODE & 344 & 1,50 &, 501 & 1 & 2 \\
\hline
\end{tabular}

Berdasarkan hasil perhitungan statistik deskriptif yang tercantum pada tabel 4.1, diketahui bahwa nilai rata-rata variabel tingkat pengungkapan sebesar 3,46. Nilai terkecil variabel tingkat pengungkapan sebesar 2. Sedangkan nilai terbesarnya sebesar 5. Variabel tingkat pengungkapan memiliki standar deviasi sebesar 0,703. 
Tabel 4.2

Tingkat Pengungkapan pada Perusahaan Asing dan Domestik

\begin{tabular}{|c|l|c|c|c|c|c|}
\hline No. & \multicolumn{1}{|c|}{ Kelompok } & Asing & Proporsi & Domestik & Proporsi & $\begin{array}{c}\text { Total } \\
\text { Proporsi }\end{array}$ \\
\hline 1. & Sangat Rendah & 0 & $0 \%$ & 0 & $0 \%$ & $0 \%$ \\
\hline 2. & Rendah & 7 & $2,04 \%$ & 11 & $3,20 \%$ & $5,24 \%$ \\
\hline 3. & Sedang & 68 & $19,77 \%$ & 105 & $30,52 \%$ & $50,29 \%$ \\
\hline 4. & Tinggi & 77 & $22,38 \%$ & 52 & $15,12 \%$ & $37,5 \%$ \\
\hline 5. & Sangat Tinggi & 20 & $5,81 \%$ & 4 & $1,16 \%$ & $6,97 \%$ \\
\hline \multicolumn{2}{r|}{ Total } & $\mathbf{1 7 2}$ & $\mathbf{5 0 \%}$ & $\mathbf{1 7 2}$ & $\mathbf{5 0 \%}$ & $\mathbf{1 0 0 \%}$ \\
\hline
\end{tabular}

Sumber: Hasil laporan keuangan tahunan yang sudah diolah.

Dari tabel diatas dapat diketahui bahwa mayoritas tingkat pengungkapan baik perusahaan asing maupun perusahaan domestik termasuk dalam kategori sedang $(0,4$ sampai 0,6) dengan total proporsi sebanyak 50,29\%. Dari tabel tersebut juga terlihat bahwa tingkat pengungkapan untuk perusahaan asing lebih tinggi bila dibandingkan dengan perusahaan domestik pada kelompok tinggi dan sangat tinggi.

\subsection{Pengujian Hipotesis}

\subsubsection{Uji Chi-Square}

Tabel 4.3.

Hasil Perhitungan Uji Chi-Square

\begin{tabular}{|l|r|r|r|}
\hline \multicolumn{3}{|c|}{ Chi-Square Tests } \\
\hline & \multicolumn{1}{|c|}{ Value } & df & Asymp. Sig. (2-sided) \\
\hline Pearson Chi-Square & $24,314(\mathrm{a})$ & 3 &, 000 \\
\hline Likelihood Ratio & 25,391 & 3 &, 000 \\
\hline Linear-by-Linear Association & 21,888 & 1 &, 000 \\
\hline N of Valid Cases & 344 & & \\
\hline
\end{tabular}

a 0 cells $(, 0 \%)$ have expected count less than 5 . The minimum expected count is 9,00 .

Sumber: Hasil olah data dengan menggunakan SPSS 13.

Berdasarkan hasil uji Chi-Square terlihat bahwa antara tingkat pengungkapan perusahaan asing dengan perusahaan domestik memiliki nilai sig sebesar $0,00<0,05$ dan nilai hitung $\chi^{2}$ sebesar $24,314>7,815$ nilai kritis $\chi^{2}$, sehingga dapat disimpulkan bahwa $\mathrm{H}_{0.1}$ ditolak. 
Tabel 4.4.

Hasil Perhitungan Uji Mann-Whitney-Wilcoxon

\begin{tabular}{|l|l|l|r|r|}
\hline \multicolumn{5}{|c|}{ Ranks } \\
\hline & KODE & N & Mean Rank & Sum of Ranks \\
\hline \multirow{3}{*}{ KODETDR } & ASING & 172 & 195,17 & 33568,50 \\
\cline { 2 - 5 } & DOMESTIK & 172 & 149,83 & 25771,50 \\
\cline { 2 - 5 } & Total & 344 & & \\
\hline
\end{tabular}

\begin{tabular}{|l|r|}
\hline \multicolumn{2}{|c|}{ Test Statistics(a) } \\
\hline & KODETDR \\
\hline Mann-Whitney U & 10893,500 \\
\hline Wilcoxon W & 25771,500 \\
\hline Z & $-4,669$ \\
\hline Asymp. Sig. (2-tailed) &, 000 \\
\hline a Grouping Variable: KODE \\
\hline
\end{tabular}

Sumber: Hasil olah data dengan menggunakan SPSS 13.

Berdasarkan hasil uji Mann-Whitney-Wilcoxon terlihat bahwa nilai $Z-4,669<$ 0,05 , sehingga dapat disimpulkan bahwa $\mathrm{H}_{0.2}$ ditolak. Tingkat pengungkapan perusahaan asing memiliki mean rank sebesar 195,17. Hasil uji menunjukkan bahwa tingkat pengungkapan perusahaan domestik memiliki mean rank yang jauh lebih rendah, yaitu sebesar 149,83, sehingga terdapat selisih mean rank sebesar 45,34.

\subsection{Interpretasi Penelitian}

Pengujian terhadap hipotesis yang pertama menyatakan bahwa terdapat perbedaan tingkat pengungkapan antara perusahaan asing dengan perusahaan domestik. Hasil pada tabel 4.3 menunjukkan angka Asymp.Sig. (2-sided) sebesar 0,000. Hasil tersebut lebih kecil dari 0,05 . Selain itu, nilai hitung $\chi^{2}$ sebesar 24,314 jauh lebih tinggi daripada nilai kritis $\chi^{2}$ yang hanya sebesar 7,815. Angka ini menunjukkan bahwa hipotesis penelitian ini diterima. Syarat sebuah hipotesis penelitian diterima adalah nilai signifikansi lebih kecil dari 0,05 dan nilai hitung $\chi^{2}>$ nilai kritis $\chi^{2}$.

Pada tabel 4.2 juga dapat dilihat bahwa tingkat pengungkapan pada perusahaan asing untuk kategori tinggi terdapat 77 perusahaan atau sebesar $22,38 \%$ dari total perusahaan yang dijadikan sampel. Tingkat pengungkapan kategori tinggi untuk perusahaan domestik hanya sebesar $15,12 \%$ atau 52 perusahaan dari total perusahaan 
yang dijadikan sampel. Tingkat pengungkapan pada perusahaan asing untuk kategori sangat tinggi sebesar 5,81\% jauh lebih tinggi proporsinya bila dibandingkan dengan tingkat pengungkapan pada perusahaan domestik yang hanya sebesar 1,16\%. Dari kedua hasil pada kategori ini dapat diketahui bahwa tingkat pengungkapan untuk perusahaan asing cenderung lebih tinggi bila dibandingkan dengan perusahaan domestik.

Hasil pengujian hipotesis yang kedua membuktikan bahwa tingkat pengungkapan perusahaan asing lebih tinggi daripada perusahaan domestik. Hasil uji Mann-WhitneyWilcoxon yang terdapat pada tabel 4.4 menunjukkan bahwa nilai $Z$ sebesar $-4,669<$ 0,05. Angka ini menunjukkan bahwa hipotesis penelitian ini diterima. Syarat sebuah hipotesis penelitian diterima adalah nilai $Z$ lebih kecil dari 0,05 .

Besarnya perbedaan tingkat pengungkapan antara perusahaan asing dan domestik dapat dilihat dari nilai mean rank pada tabel 4.4. Tingkat pengungkapan perusahaan asing memiliki mean rank sebesar 195,17. Tingkat pengungkapan perusahaan domestik memiliki mean rank yang jauh lebih rendah yaitu sebesar 149,83, sehingga terdapat selisih mean rank antara perusahaan asing dan domestik sebesar 45,34.

Hasil penelitian ini sesuai dengan dugaan awal dimana perusahaan asing cenderung memiliki tingkat pengungkapan yang lebih tinggi bila dibandingkan dengan perusahaan domestik. Hal ini sesuai dengan penelitian Susanto (1992), yang menyatakan bahwa perusahaan yang berbasis asing mungkin melakukan pengungkapan yang lebih luas. Febriana (2013) menyatakan bahwa terdapat perbedaan tingkat pengungkapan intellectual capital berdasar tingkat kepemilikan asing suatu perusahaan. Febriana menyimpulkan bahwa perusahaan dengan kepemilikan asing yang tinggi akan mengungkapkan informasi tentang intellectual capital dengan lebih lengkap. Hal tersebut dijadikan alat bagi pihak asing untuk melakukan control terhadap perusahaan dalam rangka mengurangi asimetri informasi. Hasil ini juga sesuai dengan penelitian Tamba (2011) yang menyatakan bahwa perusahaan dengan kepemilikan asing yang tinggi akan mengungkapkan informasi secara sukarela dan jelas dalam laporan keuangannya.

Penelitian yang dilakukan oleh Hadi dan Sabeni (2002) menjelaskan bahwa perusahaan asing mendapat pelatihan yang lebih baik dalam bidang akuntansi dari perusahaan induk di luar negeri, perusahaan asing mungkin memiliki sistem informasi yang lebih efisien untuk memenuhi kebutuhan internal dan perusahaan induk serta kemungkinan permintaan yang lebih besar pada perusahaan berbasis asing dari pelanggan, pemasok, dan masyarakat umum. Selain itu, perusahaan dengan kepemilikan asing tinggi memiliki teknologi yang cukup, skill karyawan yang baik, jaringan informasi yang luas, sehingga memungkinkan untuk melakukan disclosure secara lebih luas dan lebih baik (Almilia dan Retrinasari, 2007).

Perusahaan asing cenderung melakukan kegiatan ekonomi lintas negara. Untuk dapat mempermudah dalam konsolidasi laporan keuangannya, maka perusahaan menggunakan standar akuntansi global, yaitu IFRS. Dengan menerapkan IFRS, maka pengungkapan yang diungkapkan tentunya sesuai dengan standar tersebut. Dengan demikian, pengungkapan perusahaan asing cenderung lebih tinggi daripada perusahaan domestik karena lebih dahulu dalam menerapkan IFRS. 
Perusahaan domestik yang berada di Indonesia tentunya juga mengikuti standar akuntansi global yang ada, tetapi lebih lambat. Hal ini dikarenakan Indonesia perlu melakukan konvergensi dan tentunya membutuhkan waktu yang tidak singkat. Sedangkan, untuk perusahaan asing dapat lebih dahulu mengikuti standar akuntansi internasional tersebut karena adanya tuntutan dari pemilik perusahaan tersebut ataupun karena telah mengikuti standar yang ditetapkan oleh perusahaan induknya di luar negeri.

Dengan menerapkan IFRS, unsur pengungkapan yang diungkapkan menjadi lebih sesuai dengan standar global yang ada. Hal tersebut tentunya dapat meningkatkan kualitas informasi laporan tahunan perusahaan-perusahaan di Indonesia, memberikan kemudahan dalam memahami dan membandingkan informasi pada laporan keuangan secara universal, serta meningkatkan arus investasi global.

\section{Kesimpulan dan Keterbatasan Hasil Penelitian}

\subsection{Kesimpulan}

Penelitian ini membuktikan dengan diberlakukannya IFRS, terdapat perbedaan tingkat pengungkapan antara perusahaan asing dan domestik. Selain itu, penelitian ini juga membuktikan bahwa tingkat pengungkapan perusahaan asing lebih tinggi daripada perusahaan domestik. Hal ini disebabkan perusahaan asing mengikuti standar yang ditetapkan oleh perusahaan induknya di luar negeri dan perusahaan asing memiliki sistem informasi yang lebih efisien. Perlunya konvergensi dengan peraturan yang ada di Indonesia yang tentunya membutuhkan waktu yang tidak singkat mengakibatkan perusahaan domestik di Indonesia menjadi lebih lambat dalam menerapkan standar akuntansi global yang ada.

\subsection{Keterbatasan Hasil Penelitian}

Keterbatasan dalam penelitian ini adalah:

a. Sampel penelitian ini hanya menggunakan empat tahun perbandingan karena pada saat penelitian dilakukan, penerapan IFRS baru berjalan selama empat tahun yaitu dari tahun 2009 sampai tahun 2012.

b. IFRS disclosure checklist dari PwC yang digunakan pada penelitian ini hanya menggunakan IFRS disclosure checklist section A (bagian General Disclosure) dan section D.

Dengan keterbatasan sampel, periode yang diuji, dan unsur pengungkapan, maka

hasil penelitian ini hanya berlaku pada sampel, periode, dan unsur pengungkapan tersebut.

\section{Daftar Pustaka}

Almilia, L.S. dan Retrinasari, I., (2007), "Analisis Pengaruh Karakteristik Perusahaan Terhadap Kelengkapan Pengungkapan dalam Laporan Tahunan Perusahaan Manufaktur yang Terdaftar di BEJ", Proceeding Seminar Nasional: Inovasi dalam Menghadapi Perubahan Lingkungan Bisnis. Diakses dari http://www.almilia.com/wp- 
content/uploads/2008/08/penelitian-faktor-kelengkapan-pengungkapan.pdf pada tanggal 15 Oktober 2014.

Bova, F., dan Pereira, R., (2012), "The Determinants and Consequences of Heterogenenous IFRS Compliance Levels Following Mandatory IFRS Adoption: Evidence from a Developing Country", Journal of International Accounting Research 11(1): 83-111.

Dahawy, K., (2009), "Company Characteristics and Disclosure Level: The Case of Egypt", International Research Journal of Finance and Economics (34): 194-208.

Farahmita, Aria., (2012), "Analisis Faktor-Faktor yang Mempengaruhi Kemungkinan Adopsi IFRS di Negara Berkembang”, Skripsi, Fakultas Ekonomi Universitas Indonesia.

Hadi, N. dan A. Sabeni., (2002), "Analisa Faktor-Faktor yang Mempengaruhi Luas Pengungkapan Sukarela Dalam Laporan Tahunan Perusahaan Go Publik di Bursa Efek Jakarta”, Jurnal Maksi, Vol. 1, hal. 90-105.

Ikatan Akuntan Indonesia., (2009), "Standar Akuntansi Keuangan Per 1 Juli 2009”, Penerbit Salemba Empat, Jakarta.

Irfan, A., (2002). "Pelaporan Keuangan dan Asimetri Informasi dalam Hubungan Agensi", Lintasan Ekonomi, Vol. XIX No.2 Juli 2002.

Mardini, G.,Cwarford, L.,dan Power, D. M.,(2012), "The Impact of IFRS 8 on Disclosure Practices of Jordanian Listed Companies", Journal of Accounting in Emerging Economies, Vol. 2 No.1, Emerald Group Publishing Limited.

Nobes, C. Parker, R., (2010), “Comparative International Accounting", Prentice Hall, $11^{\text {th }}$ edition, England.

Pramono, (2006), "Pengaruh Modal, Likuiditas, dan Efisiensi terhadap Pemberian Kredit pada PT Bank Rakyat Indonesia (Persero) Tbk Periode 2001-2005", Diponegoro Journal of Management, Vol. 1, Nomor 2, Tahun 2006, Hal. 80-91.

Sudarmadji, A.M. dan Sularto, L., (2007), "Pengaruh Ukuran Perusahaan, Profitabilitas, Leverage, dan Tipe Kepemilikan Perusahaan Terhadap Luas Voluntary Disclosure Laporan Keuangan Tahunan", Proceeding PESAT 2.

Susanto, D., (1992), "An Empirical Investigation of the Corporate Disclosure in Annual Reports of Companies Listed on the Jakarta Stock Exchange", Tim Koordinasi Pengembangan Akuntansi Jakarta, Disertasi S3: University of Arkansas.

Tamba, E., (2011), "Pengaruh Struktur Kepemilikan terhadap Pengungkapan Tanggung Jawab Sosial".

Utami, W. D., Suhardjanto, D., Hartoko, S., (2012), "Investigasi Konvergensi IFRS di Indonesia: Tingkat Kepatuhan Pengungkapan Wajib dan Kaitannya dengan 
Mekanisme Corporate Governance", diakses dari http://asp.trunojoyo.ac.id/wpcontent/uploads/2014/03/066-CG-20.pdf pada tanggal 10 Oktober 2013.

UU No.1 Tahun 1995 Tentang Perseroan Terbatas.

Undang-Undang No. 25 Tahun 2007 Tentang Penanaman Modal. 